\title{
Characterization and diversity of rhizobia nodulating selected tree legumes in Ghana
}

\author{
Emmanuel Yaw Boakye ${ }^{1}$ - Innocent Yao Dotse Lawson ${ }^{1}$. \\ Seth Kofi Akyea Danso ${ }^{1}$ - Samuel Kwame offei ${ }^{1}$
}

Received: 22 April 2015 / Accepted: 5 February 2016/Published online: 18 February 2016

(C) The Author(s) 2016. This article is published with open access at Springerlink.com

\begin{abstract}
The study was conducted to assess the characteristics and diversity of the rhizobia that nodulate some prominent tree legumes in three soils of Ghana. Five introduced and/or indigenous tree legumes were initially assessed for nodulation in three Ghanaian soils. After 12 weeks of growth in nursery pots the 200 rhizobial strains isolated from their nodules were characterized culturally, metabolically and phenotypically. Sixty of these isolates were selected randomly and their genotypic characteristics determined using PCR-RFLP of $16 \mathrm{~S}$ rRNA and intergenic spacer (ITS) genes. Each tree legume was nodulated by isolates classified as fast or very fastgrowers or by isolates classified as slow- or very slowgrowers with $54 \%$ of all the 200 isolates belonging to fastor very fast-growers. Morphologically, eighty five percent of the colonies formed on yeast extract mannitol agar were wet and gummy while $70 \%$ were acid tolerant, i.e. they were able to grow at a $\mathrm{pH}$ of 3.5. Combined restriction of the $16 \mathrm{~S}$ rRNA genes of the 60 rhizobial isolates with five restriction enzymes clearly distinguished seven different clusters at $80 \%$ similarity level. The majority of $A$. lebbeck isolates were distinct from those of the Acacias and L. leucocephala. The M. thonningii isolates were related to L. leucocephala isolates. Simple PCR of the ITS DNA provided several distinct band sizes indicating great variation among the isolates and restriction of the ITS with three different enzymes did not yield many further differences. Molecular techniques revealed a great diversity among the rhizobia that nodulate tree legumes in the tropics
\end{abstract}

Emmanuel Yaw Boakye greatkosaltd@yahoo.com

1 College of Agriculture and Consumer Sciences, Department of Soil Science, University of Ghana Legon, P. O. Box 245, Legon, Ghana and this may explain why many introduced and/or indigenous trees are able to form nodules with indigenous rhizobia in this region.

Keywords Characterization $\cdot$ Diversity $\cdot$ Rhizobium $\cdot$ Tree legumes

\section{Introduction}

Rhizobia are usually defined as nitrogen-fixing soil bacteria capable of inducing the formation of root or stem nodules on leguminous plants in which atmospheric nitrogen is reduced to ammonia for the benefit of the plant. Although the majority of legumes form symbiosis with members of genera that belong to the class Alphaproteobacteria (Allorhizobium, Azorhizobium, Blastobacter, Bradyrhizobium, Devosia, Ensifer, Mesorhizobium, Methylobacterium, Rhizobium and Sinorhizobium), some legumes, such as those in the large genus Mimosa, are nodulated predominately by members of the class Betaproteobacteria in the genera Burkholderia and Cupriavidus (Gyaneshwar et al. 2011). However, a recent report by Bontemps et al. (2015) indicated that the endemic Mexican mimosas unlike their Brazillian counterparts were nodulated predominantly by Alphaproteobacteria from the genera Rhizobium and Ensifer.

In the last few years, many studies investigating rhizobia isolated from tree legumes in Kenya and Sudan have revealed considerable phenotypic and genotypic diversity among strains, and several distinct groups have been identified and novel species described (Zhang et al. 1991; Odee et al. 1997, 2002; Nick et al. 1999; McInroy et al. 1999). These studies concluded that there is a large heterogeneity among the strains (Crow et al. 1981; De Lajudie et al. 1994; Dupuy et al. 1994; Jarvis 1983; Moreira et al. 1998; Zhang et al. 1991). This 
indicates that trees can form nodules and fix nitrogen with several different groups of rhizobia (Crow et al. 1981; Jarvis 1983; Lindstrom et al. 1983; Padmonabhan et al. 1990).

Of late, the assessment of diversity within rhizobial natural populations in various regions of the world has received increasing attention (Amann et al. 1995; Batzli et al. 1992; Brunel et al. 1996; Cartwright et al. 1995). Many attempts have been made to determine the actual composition and characteristics of indigenous strains isolated from different cultivated legumes (Chen et al. 1991; Crow et al. 1981) and also from less explored plants (Felsenstein 1985). The development of molecular genetic methods and the availability of sensitive and accurate PCR- based fingerprinting methods (Galtier et al. 1996; Gibson 1980; Gurtler 1993) has enabled the differentiation of closely related bacterial strains and the detection of high rhizobial diversity (Gurtler and Stanisich 1996; Jarvis 1983; Jarvis et al. 1982).

In Ghana, with the exception of studies on cowpea rhizobia (Fening 1999) there is little knowledge of the diversity of rhizobia that nodulate other legumes especially tree legumes. The aim of the present study was to assess the phenotypic and genotypic characteristics of the rhizobia including their diversity that nodulate some indigenous and introduced tree legumes in Ghana.

\section{Materials and methods}

\subsection{Soil and site characteristics}

The three soil types used for the studies were taken from the Accra plains $\left(05^{\circ} 39.627^{1} \mathrm{~N}, 0011.619^{1} \mathrm{~W}\right)$. The soils belong to the Toje, Hatso and Alajo series (Local Names) (Brammer 1967). The Toje series is classified as Rhodic lixiso, and the Hatso and Alajo series classified as Haplic lixisol and Calcic vertisol, respectively, according to FAO (2006). The three soils are widely cultivated by resource-poor farmers in the area and occur on the same soil catena with Toje series being at the top, Hatso and Alajo series being at the middle and the bottom slope, respectively.

\subsection{Soil analysis}

Soil $\mathrm{pH}$ was determined in distilled water at a soil: solution ratio of 1:1 using Pracitronic M.V 88 pH electrometer (Peech 1965). Organic carbon was determined using the wet combustion method of Walkley and Black (1934) while the Bray and Kurtz (1945) method was used to measure available phosphorus. Total nitrogen was determined by the distillation and titration method of Bremner (1965). The cation exchange capacity (CEC) of the soils was determined by extraction of the exchangeable bases using neutral ammonium acetate (NH4OAc, $\mathrm{pH}$ 7.0) and an aliquot was used to determined
$\mathrm{Ca}, \mathrm{Mg}, \mathrm{K}$ and $\mathrm{Na}$. Soil texture was determined based on particle size analysis using the modified Bouyoucos hydrometer method as describe by Day (1965).

\subsection{Initial nodulation studies}

Seeds of one indigenous (Milletia thonningii) and four introduced (Albizia lebbeck, Acacia auriculiformis, Acacia mangium and Leucaena leucocephala) tree legumes were initially assessed for their nodulation potential in three different soil types by growing them in pots filled with two kilograms of each soil type for 12 weeks. Representative nodules were collected for rhizobia isolation.

\subsection{Rhizobia enumeration in the three soils}

The population of indigenous rhizobia in the three different soils capable of nodulating the selected tree legumes (Albizia lebbeck, Acacia auriculiformis, Acacia mangium, Leucaena leucocephala and Milletia thonningii) were enumerated based on the most probable number (MPN) method (Vincent 1970) using plastic growth pouches (Weaver and Frederick 1972). Clean seeds of the tree legumes were surface sterilized in $70 \%$ alcohol for $3 \mathrm{~min}$ and rinsed thoroughly in several changes of distilled water (Somasegaran and Hoben 1994). The seeds were scarified and pregerminated on $1 \%$ water agar until the radicles were about $2 \mathrm{~cm}$ long. Seedlings were planted two per pouch. Ten-fold dilutions of each soil sample with four replicates per dilution were used to inoculate the pouches containing $\mathrm{N}$-free nutrient solution (Somasegaran and Hoben 1994). One milliliters of soil inoculants was used to inoculate each pouch. The pouches were randomly arranged in wooden racks and kept at the green house. The plants were supplied when necessary with enough $\mathrm{N}$-free nutrient solution to prevent wilting and other nutrient deficiencies. The plants were assessed for nodules after 12 weeks and the most probable number of rhizobia calculated (Vincent 1970).

\subsection{Rhizobia isolation}

Representative nodule samples were taken from the initial nodulation study. The nodules were surface sterilized with $70 \%$ alcohol for $3 \mathrm{~min}$ and then with $0.1 \%$ mercuric chloride for another $3 \mathrm{~min}$ and rinsed with several washes in sterile distilled water (Somasegaran and Hoben 1994). The nodules were each crushed in a drop of sterile distilled water in a petri dish with a sterile rod. A loop-full of the suspension was then streaked on yeast extract mannitol (YEM) agar plates and incubated at $28{ }^{\circ} \mathrm{C}$. A total of 400 rhizobia isolates were obtained from the five legumes. 


\subsection{Authentication of isolates}

All the rhizobia isolates were evaluated as pure cultures that could form nodules on their respective host plants. Seeds of the leguminous plants were pre-germinated in petri-dish after scarification with conc. $\mathrm{H}_{2} \mathrm{SO} 4$. The pregerminated seeds were planted in growth pouches containing $\mathrm{N}$-free nutrient solution (Somasegaran and Hoben 1994). Seven days after planting, the growth pouches were inoculated with $1 \mathrm{ml}$ YEM broth culture of each isolate with each treatment replicated four times. Uninoculated pouches served as control. The pouches were placed in racks and kept in the green house. Plants were harvested 12 weeks after planting and their roots assessed for the presence of nodules. Two hundred out of an initial total of 400 rhizobial isolates made up from 40 isolates each from the following five tree legume, A. lebbeck, A. auriculiformis, A. mangium, L. leucocephala and M. thonningii, were randomly selected for characterization and further studies.

\subsection{Culture maintenance}

All rhizobial isolates were maintained on YEM slopes and stored at $4{ }^{\circ} \mathrm{C}$. All rhizobial isolates were re-plated on YEM and checked for contamination at least every three months.

\subsection{Physiologic and metabolic characterization of the rhizobia isolates}

Two hundred indigenous tree legume rhizobia isolates from the three soils were selected and used for these studies. The studies include the following:

\subsection{Growth rate, reaction to BTB and colony morphology}

The time taken for the isolates to form colonies on YEM agar plates was followed for 7 days, and the ability of the isolates to change the $\mathrm{pH}$ of their growth medium was scored on YEM agar plates supplemented with $0.25 \mathrm{mg} / \mathrm{L}$ bromothymol blue(BTB). Plates were incubated for 7 days at $30{ }^{\circ} \mathrm{C}$ and scored daily for change in colour. Freshly prepared YEM plates containing BTB have a $\mathrm{pH}$ of 6.8 and are green in colour. The isolates that changed the colour of the medium to yellow were scored as acid producers and classified as fast growers. Isolates that changed the medium to blue were considered alkalisers and classified as slow growers. Colony appearance was scored as dry where the surface was smooth and firm, and wet for those which were watery or slimy.
2.10 Growth of the tree legume rhizobia in different $\mathrm{pH}$ medium

The $\mathrm{pH}$ values of tubes containing $20 \mathrm{ml}$ of YEM broth without $\mathrm{KH}_{2} \mathrm{PO}_{4}$ (Zablotowicz and Focht 1981), were adjusted ( $\mathrm{pH}$ values see below) before sterilization by the addition of $\mathrm{HCL}$ or $\mathrm{NaOH}$. The tubes were inoculated with $100 \mu \mathrm{L}$ aliquots of each isolate and incubated at $28^{\circ} \mathrm{C}$ for 7 days before scoring for growth by observation for turbidity and confirmation by colony counting on plates. Growth was determined at $\mathrm{pH} 3.5,4.5,5.5,6.5$ in the acid range and $\mathrm{pH} 7.5,8.5$ and 9.5 in the alkaline range.

\subsection{Ability of tree legume rhizobia to utilize different carbon}

The rhizobia isolates were tested for their ability to grow when provided with different carbohydrates as the sole carbon source. The test was carried out in a standard basal medium without mannitol (Zablotowicz and Focht 1981). Each carbohydrate was added to a final concentration of $10 \%(\mathrm{~W} / \mathrm{V})$. The carbohydrates were sterilized by filtration through Millipore membranes (pore size $0.22 \mu \mathrm{m}$ ) and then added to the sterilized liquefied medium just before plates were poured. Each isolate was analysed on duplicate plates and the growth scored after incubation for seven days at a temperature of $28^{\circ} \mathrm{C}$. The following carbohydrate sources were tested: L-arabinose, D-glucose, Dgalactose, fructose, lactose, maltose, mannitol and sucrose.

\subsection{Molecular characterization of some tree legume rhizobial isolates}

A total of 60 tree legume rhizobial isolates which were considered as representative strains of the 200 isolates were selected for further molecular studies.

\subsection{DNA extraction.}

The rhizobial isolates were cultivated on YEM agar plates at $28{ }^{\circ} \mathrm{C}$ for 5 days. Single colonies of the rhizobial isolates were picked, washed in $100 \mu \mathrm{TE}$ at ${ }_{\mathrm{P}} \mathrm{H} 7.5$ and spun down (Sally et al. 2010). $250 \mu$ of CTAB buffer were added to the washed cells; they were vortexed for $30 \mathrm{~s}$, and incubated at $65^{\circ} \mathrm{C}$ for $15 \mathrm{~min}$ and then cooled down to room temperature (Sally et al. 2010). $250 \mu \mathrm{l}$ of $24: 1$ chloroform: isoamyl alcohol was added to the samples and vortexed thoroughly. The suspension was then centrifuged for $10 \mathrm{~min}$ at $12,000 \mathrm{rpm}$ using a fixed angle rotor. The aqueous phase was transferred to a new sterile $1.5 \mathrm{ml}$ micro centrifuge tube and equal amounts of cold isopropanol added and mixed gently (Sally et al. 2010). The DNA was precipitated at $-20{ }^{\circ} \mathrm{C}$ for $30 \mathrm{~min}$ and centrifuged for $10 \mathrm{~min}$ at $12,000 \mathrm{rpm}$. The DNA was resuspended in $30 \mu \mathrm{l} \mathrm{TE}$ buffer at ${ }_{\mathrm{P}} \mathrm{H} 7.4$ and the concentration 
of the extracted DNA assessed at $260 \mathrm{~nm}$ using a Nanodrop Spectrophotometer (Sally et al. 2010).

\subsection{PCR amplication of 16S rRNA gene}

The universal primers fD1 $\left(5^{1}\right.$ - AGAGTTTGATCCTG GCTCAG- $\left.3^{1}\right)$ and rD1. (5 ${ }^{1}$ - AAGGAGGTGATCCAGCC$3^{1}$ ) were used for PCR amplification of the $16 \mathrm{~S}$ rRNA (Weisburg et al. 1991). fD1 and rD1 are primers derived from conserved regions of the $16 \mathrm{~S}$ rRNA genes and amplify nearly full length of 16S rRNA genes (Weisburg et al. 1991). Amplification reactions were performed in a total volume of $25 \mu \mathrm{l}$ and contain the following: $1 \times$ reaction buffer $(10 \mathrm{Mm}$ Tris-Hcl, $50 \mathrm{MmKcl}$ ) with $1.5 \mathrm{mM} \mathrm{MgCl}_{2}, 2.5$ units Taq polymerase, $200 \mu \mathrm{M}$ of each dNTP (dATP, dCTP, dGTP and dTTP ), 5 pmol of each forward and reverse primer and $100 \mathrm{ng}$ of genomic DNA. The temperature profile was as follows: Initial denaturation at $95^{\circ} \mathrm{C}$ for $3 \mathrm{~min} ; 35$ cycles of denaturation at $94^{\circ} \mathrm{C}$ for $1 \mathrm{~min}$, annealing at $55^{\circ} \mathrm{C}$ for $1 \mathrm{~min}$, extension at $72^{\circ} \mathrm{C}$ for $2 \mathrm{~min}$ and final extension at $72{ }^{\circ} \mathrm{C}$ for $3 \mathrm{~min}$. The amplified products were kept at a temperature of $4{ }^{\circ} \mathrm{C}$. All amplifications were carried out in Thermocycler (Bio-Rad).

\subsection{PCR amplification of 16S-23S intergenic spacer (ITS)}

The intergenic region between the $16 \mathrm{~S}$ and the $23 \mathrm{~S}$ rRNAs was amplified by PCR with primers derived from the $3^{1}$ end of the $16 \mathrm{~S}$ rRNA (FGPS1490-72; 5 ${ }^{1}$-TGCGGCTGGATC CCCTCCTT- $3^{1}$ ) and from the $5^{1}$ end of the $23 \mathrm{~S}$ rRNA (FGPL132-38; $5^{1}$-CCGGGTTTCCCCATTCGG- ${ }^{1}$ ) (Ponsonnet and Nesme 1994). The amplification reactions and conditions were the same as those used for 16S rRNA amplification.

\subsection{Gel electrophoresis and imaging}

The resulting amplicons $(5 \mu \mathrm{l})$ of the $16 \mathrm{~S}$ rRNA and ITS genes were mixed with loading buffer $(2 \mu \mathrm{l})$ and analysed electrophoretically through $1 \%$ agarose gel stained with ethidium bromide $(10 \mathrm{mg} / \mathrm{ml})$ at $100 \mathrm{~V}$ for $1 \mathrm{~h}$. The bands were observed and photographed under UV light using BioDoc-IT imaging system.

\subsection{Restriction fragment length polymorphism (RFLP) analysis of the 16S rRNA and ITS}

Aliquots $(10 \mu \mathrm{L})$ of the $16 \mathrm{~S}$ rRNA and ITS PCR products were digested with restriction endonucleases as specified by the manufacturer (Bioron $\mathrm{GmbH}$ ) with $5 \mathrm{U}$ of enzyme per reaction in a total volume of $25 \mu \mathrm{L}$. The following enzymes were used for the $16 \mathrm{~S}$ amplicon digestion: HaeIII, AluI, $\mathrm{HPaII}, \mathrm{HPaI}$ and RsaI. The ITS amplicons were digested with three enzymes namely HaeIII, Alu I and HPaII.
The restriction fragments were separated by horizontal electrophoresis in TBE buffer ( $89 \mathrm{mM}$ Tris, $89 \mathrm{mM}$ boric acid, 2 mM EDTA $(\mathrm{pH} 8.0)$ on a $2 \%(w / v)$ agarose gel containing $10 \mathrm{mg}$ of ethidium bromide per $\mathrm{ml}$. The gels were run at $80 \mathrm{~V}$ for $2 \mathrm{~h}$ and immediately photographed under UV light using Bio-Doc-IT imaging system.

\section{Results}

\subsection{Soil properties}

The characteristics of the soils used in this study are presented in Table 1. The Alajo series with a clay loam texture had the highest values for all parameters measured, while the Hatso series, a sandy soil was lowest in total $\mathrm{N}$, organic carbon and available $\mathrm{P}$, whereas the Toje series, a sandy clay loam was lowest in $\mathrm{pH}$ and $\mathrm{CEC}$ values.

\subsection{Enumeration of native rhizobia capable of nodulating five selected indigenous tree legumes}

Table 2 provides information on the population densities of native rhizobia capable of nodulating five of the tree legumes in the three soil types. The results indicate that, native rhizobia capable of nodulating each of the five tree legumes are present in all the three soils used for the study with the native rhizobia population ranging from 22 per gram of soil in Alajo soil to 5200 per gram of soil in either Hatso or Toje soil. In all cases, the highest rhizobia population per gram of soil capable of nodulating the tree legumes was highest in Hatso soil, followed by Toje soil and lowest in Alajo soil.

\subsection{Physiologic and metabolic properties of some indigenous tree legume rhizobia}

The rhizobia that nodulated the five tree species under analysis were diverse in colony morphology, reaction with BTB, growth at different $\mathrm{pH}$ ranges as well as in their ability to utilize different carbon sources.

Table 1 Chemical properties of the soils used for this study

\begin{tabular}{llll}
\hline Parameters & \multicolumn{2}{l}{ Soil types } & \\
\cline { 2 - 3 } & Toje & Hatso & Alajo \\
\hline $\mathrm{pH}$ & 5.3 & 6.0 & 6.8 \\
Total $\left(\mathrm{g} \mathrm{kg}^{-1}\right)$ & 0.59 & 0.34 & 1.34 \\
Organic carbon $\left(\mathrm{g} \mathrm{kg}^{-1}\right)$ & 6.5 & 3.7 & 13.9 \\
$\mathrm{CEC}(\mathrm{cmol} \mathrm{kg}$ & \\
Available $\mathrm{P}\left(\mathrm{mg} \mathrm{kg}^{-1}\right)$ & 5.84 & 7.40 & 25.20 \\
Texture & 7.52 & 3.76 & 12.4 \\
\hline
\end{tabular}


Table 2 Indigenous rhizobia population /g soil in the Toje, Hatso and Alajo soils

\begin{tabular}{llll}
\hline \multirow{2}{*}{ Tree species } & \multicolumn{3}{l}{ Rhizobia population /g of soil } \\
\cline { 2 - 4 } & TOJE & HATSO & ALAJO \\
\hline Albizia lebbeck & 780 & 5200 & 1800 \\
A. auriculiformis & 520 & 1800 & 180 \\
A. mangium & 180 & 210 & 22 \\
Leucaena leucocephala & 780 & 1800 & 650 \\
Milletia thonningii & 5200 & 5200 & 780 \\
\hline
\end{tabular}

Fifty four percent (54\%) of the total isolates acidified YEM medium and were considered as fast or very fast growers with the rest (46\%) alkalizing the medium and classified as being slow or very slow growers. Each tree legume harboured all the various types of rhizobia strains in its nodules (Fig. 1). While both types were represented in the nodules on each tree, which one was in the majority was dictated by the tree species (Fig. 1). Thus while A. mangium, $A$. auriculiformis and L. leucocephala were predominantly nodulated by slow-growers strains with $45 \%, 45 \%$ and $48 \%$ respectively, the other tree legumes; $A$. lebbeck and $M$ thonningii were predominantly nodulated by fast-growers (Fig. 1). For example, $53 \%$ and $43 \%$, respectively, of the rhizobia that nodulated A. lebbeck and M. thonningii were fast growers.

Each tree legume was nodulated by rhizobia forming all three colony types, dry (D), wet gummy firm (WGF), and wet gummy soft (WGS) except for A. mangium that was nodulated by only wet gummy firm and wet gummy soft rhizobial isolates (Fig. 2). Apart from A. auriculiformis and M. thonningii which were predominantly nodulated by wet gummy firm rhizobia isolates, all the other tree legumes were predominantly nodulated by wet gummy soft rhizobial isolates (Fig. 2). For instance, A. lebbeck, L. leucocephala and A. mangium were predominantly nodulated by $50 \%, 62.5 \%$ and $80 \%$, respectively, of wet gummy soft rhizobia isolates. In all, only $15 \%$ of the total isolates were considered dry whilst $32.5 \%$ and $52.5 \%$ were considered wet gummy firm and wet gummy soft, respectively. All the isolates from the Alajo soil series that nodulated the tree legumes were considered wet gummy soft but the Toje and Hatso soil series harboured all the three types of isolates (i.e., dry, wet gummy firm and wet gummy soft).

Isolates from each tree legume varied in terms of their ability to grow in media at different $\mathrm{pH}$ levels (Fig. 3). In general, the inability of the tree legume rhizobial isolates to grow in media with different $\mathrm{pH}$ increased with decreasing $\mathrm{pH}$ levels. For instance, at a $\mathrm{pH}$ of 3.5, $40 \%$ and $35 \%$, respectively, of $A$. lebbeck and A. mangium rhizobial isolates did not grow and also $30 \%$ each of $A$. auriculiformis and $L$. leucocephala rhizobial isolates could not grow. In contrast, almost all the tree legume isolates could grow in the alkaline pH range from 7.5 to 9.5 (Fig. 3).

Thirty percent of the total of 200 isolates could not grow at a pH of 3.5 while $13.5 \%$ and $7 \%$, respectively, could not grow at $\mathrm{pH} 4.5$ and 5.5 , respectively. The majority of the total isolates that could not grow at acidic $\mathrm{pH}$ ranges $(\mathrm{pH} 3.5,4.5$ and 5.5) were fast growers. However, more than $77 \%$ and $71 \%$, respectively, of the total isolates that could not grow at pH 4.5 and 5.5, respectively, were slow growers.

\subsection{Molecular characterization of 60 rhizobial isolates of some tree legumes}

Sixty of the rhizobia isolates were randomly selected as representative strains of the tree legumes rhizobia after phenotypic characterization. The relationships among the isolates were then assessed using molecular tools. Table 3 provides a list of strains used for this study and their host legumes.

\subsection{PCR amplification and RFLP analysis of 16S rRNA genes of some tree legumes rhizobia}

PCR amplification of 16S rRNA genes of almost all the 60 rhizobia isolates of the tree legumes produced a single band $1.5 \mathrm{~kb}$ in size. Restriction of the $16 \mathrm{~S}$ rRNA amplicons of the
Fig 1 Classification of 40 rhizobial isolates obtained from each of the five tree legumes based on number of days taken for colonies to form on YEM

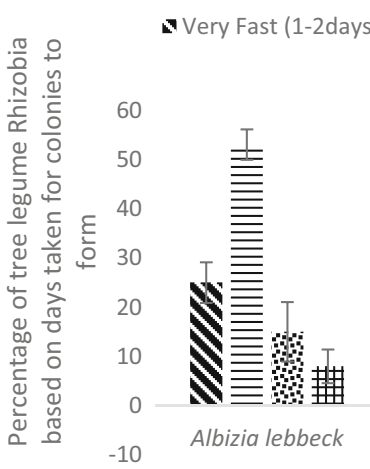

= Fast (3-5days) a Slow (6-7days) \# Very Slow (7days or more)
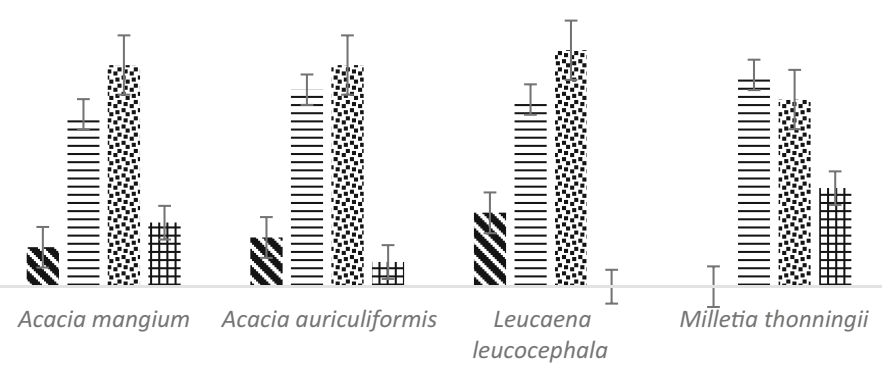

Tree legumes 
Fig. 2 Classification based on colony morphology of 40 rhizobial isolates that nodulated each of the five tree legumes

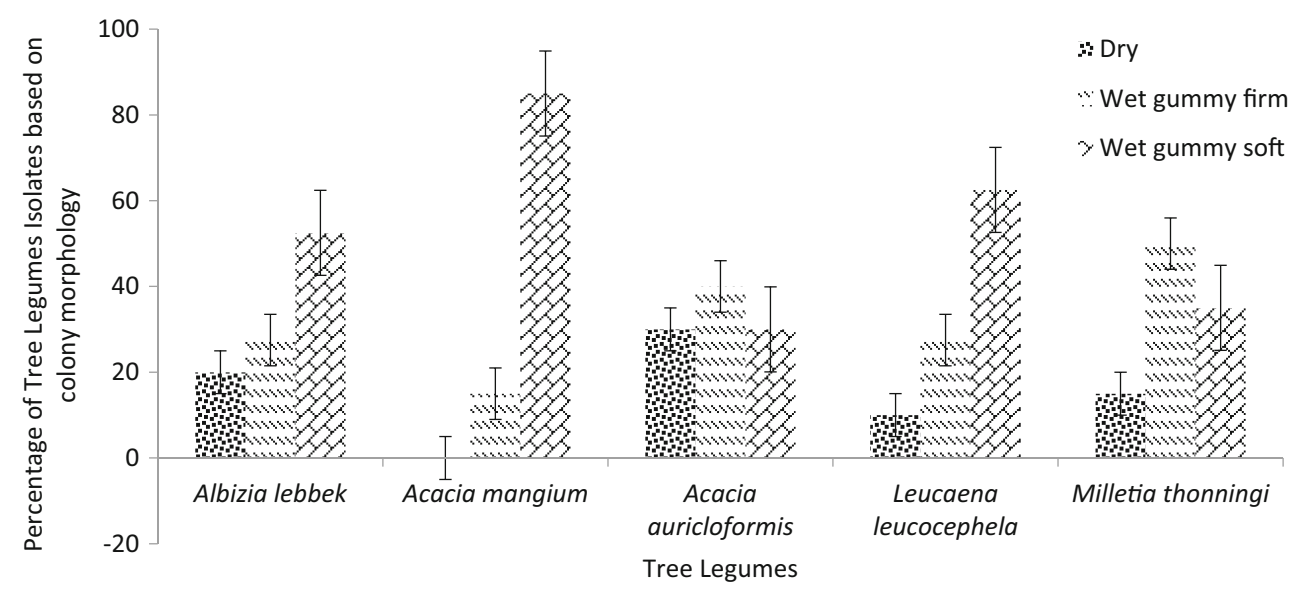

rhizobial isolated from the different legumes with any of the restriction enzymes Hae111, Alu1, HpaI, HpaII and Rsa1 produced multiple bands. Although each restriction enzyme produced polymorphic band patterns, the most diverse were those obtained with Rsa1 and HpaII; the latter are shown in Fig. 4.

Combined restriction of the $16 \mathrm{~S}$ rRNA amplicons with the five restriction enzymes distinguished clearly between two major clusters A and B at $45 \%$ similarity levels which were further separated into six distinct clusters (I - VI) at $80 \%$ similarity level (Fig. 5). Out of a total of sixty isolates, cluster A consisted of 13 isolates that were genetically distinct from cluster B which consisted of 47 isolates. None of the clusters (I-VI) contained isolates obtained from all the five tree legumes. Rather, each cluster contained isolates that were dominated by rhizobia from one or two legume species. For instance, most of the isolates in cluster I were those obtained from $A$. lebbeck (62\%), while cluster II was dominated by isolates obtained from the two acacias (79 \%). Almost $56 \%$ of the isolates in cluster III were from L. leucocephala. Isolates obtained from M. thonningii and L. leucocephala which appeared similar at $80 \%$ similarity level also formed almost $77 \%$ of the isolates in cluster V. Isolate 53 obtained from $A$. mangium appeared distinct at $80 \%$ similarity level. Generally, the majority of the isolates were separated at a similarity levels between $80 \%$ and $90 \%$.

\subsection{PCR amplification and RFLP analysis of the $16 \mathrm{~S}$ and $23 \mathrm{~S}$ rRNA intergenic spacer (ITS) amplicon of some isolates from indigenous tree legumes}

PCR amplification of the intergenic spacer (ITS) between the $16 \mathrm{~S}$ and $23 \mathrm{~S}$ rRNA genes of all the strains produced multiple polymorphic bands with size ranging from $800 \mathrm{bp}-1.4 \mathrm{kbp}$ (Fig. 6). Cluster analysis of undigested PCR product of the isolates ITS shows that, the isolates could be grouped into two main clusters namely A and B at about $10 \%$ similarity level (Fig. 5). Cluster A consist of isolates that were predominantly obtained from A. lebbeck, A. mangium and A. auriculiformis whiles cluster B consist of isolates that were predominantly obtained from L. leucocephala and M. thonningii. Each cluster was further separated into sub-groups with each sub-group containing a mixture of isolates obtained from all the tree legumes.

Restriction of the ITS with the three enzymes HaeIII, AluI and HpaII did not allow much further differentiation among the isolates.
Fig. 3 Effect of six different $\mathrm{pH}$ levels on growth of 40 rhizobial isolated from each of the five tree legumes

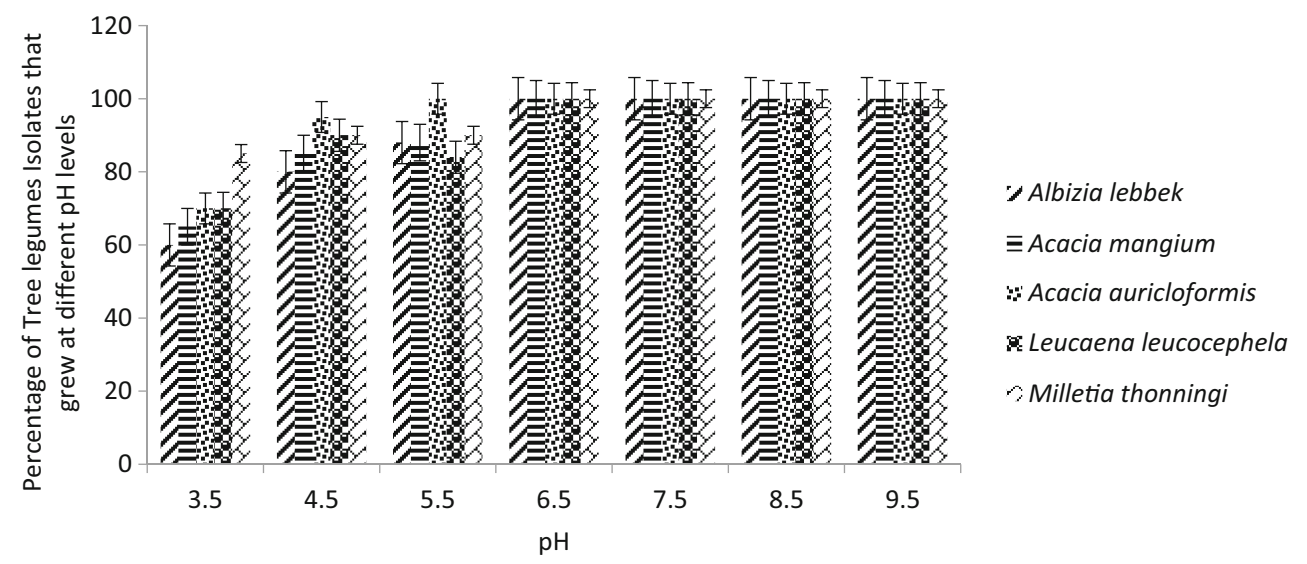


Table 3 List of isolates used in this studyand their respective host legumes

\begin{tabular}{ll}
\hline Host Tree Legumes & Isolate numbers \\
\hline Albizia lebbeck & $2,3,4,6,7,8,9,10,15,30,42,45,48,51$. \\
Acacia mangium & $5,11,12,13,14,17,20,53,58,61,62$. \\
$\begin{array}{l}\text { Acacia auriculiformis } \\
\text { Leucaena }\end{array}$ & $1,16,21,23,24,25,26,28,52,54,55,56,57$. \\
$\quad$ leucocephala & $19,22,27,31,33,35,37,38,39,40,50$ \\
Milletia thonningii & $18,29,32,34,36,43,44,47,49,59,60$ \\
\hline
\end{tabular}

\section{Discussion}

Bacteria belonging to the family of Rhizobiaceae were divided into two groups on the basis of their growth rate on YEM medium. These were the fast-growing rhizobia and the slowgrowing rhizobia. The results showed that each tree legume was nodulated by both types of rhizobia, but which one formed the majority was dependent on the tree species. The results also showed presence of both types of rhizobia in all the three soils studied, which is consistent with their appearance in many tropical soils as reported in earlier studies (Sanginga et al. 1989; Dreyfus and Dommergues 1981).

This has also been reported by other researchers (Moreira et al. 1998; Trinick 1980; Turk and Keyser 1992; Zhang et al. 1991).

Some studies (e.g. Sanginga et al. 1989) gave the impression that slow-growing rhizobia dominate in tropical soils, Our results showed the reverse with $54 \%$ of nodules of all five trees being formed by fast- growing species. Sanginga et al. (1989) reported that although L. leucocephala was nodulated by both fast and slow-growing rhizobia, only effective nitrogen fixing nodules were formed with the fastgrowing rhizobia. These findings suggest that the fastgrowing rhizobia are more important in $\mathrm{N}_{2}$ fixation in tropical soils than has been assumed.
On the basis of rhizobial growth on YEM medium amended with a $\mathrm{pH}$ indicator, the isolates were classified as acid producers or as alkalizers. Our results showed that each legume was nodulated by both types of rhizobia although the acid producers were more prominent than the alkalizers. This suggests that acid producers are important in nodulation and nitrogen fixation in tree legumes in tropical soils which tend to be acidic or slightly acidic.

The high rhizobial population observed in the three soils might be due to the fact that these soils had earlier been used to cultivate legumes belonging to the same cross inoculation groups as the tree legumes. Fast-growing rhizobia are generally considered to be less tolerant of acidic conditions than slow-growing strains (Graham et al. 1994), However, analysis of the $\mathrm{pH}$ tolerance of the tree legume rhizobia indicated that most of the tree legume rhizobia were fast-growers and acid tolerant. Indeed $70 \%$ of all isolates could grow at a $\mathrm{pH}$ of 3.5 . Other researchers have found the existence of fast-growers that are tolerant to acid conditions (Cooper et al. 1985; Cunningham and Munns 1984, Graham et al. 1994, Wood et al. 1988). Further support for the existence of acid-tolerant fast-growing strains come from studies on strains nodulating Vigna unguiculata which are tolerant to $\mathrm{pH}$ values as low as 4 (Mpepereki et al. 1997.) This tolerance to acidic conditions may reflect the fact $t$ that the majority of the strains were isolated from slightly to moderately acid soils and hence were adapted to such conditions.

Amplification of the 16S rRNA gene of almost all the rhizobia isolates used in this study resulted in a single band $1.5 \mathrm{~kb}$ in size. This band size correspond to the expected size reported earlier by Weisburg et al. (1991) and Terefework et al. (1998). Combined restriction of the 16S rRNA genes of the rhizobia isolates with five endonucleases distinguished clearly six different combinations of patterns or fingerprints at $80 \%$ similarity level which represents six distinct $16 \mathrm{~S}$ rRNA genotypes among the isolates. This finding indicates great

Fig. 4 Restriction patterns of PCR-amplified 16S rRNA digested with HpaII. Molecular size marker (M): $2 \mathrm{k}$ bp ladder. $\mathrm{U}$ is the control representing an uncut 16S rRNA amplicon

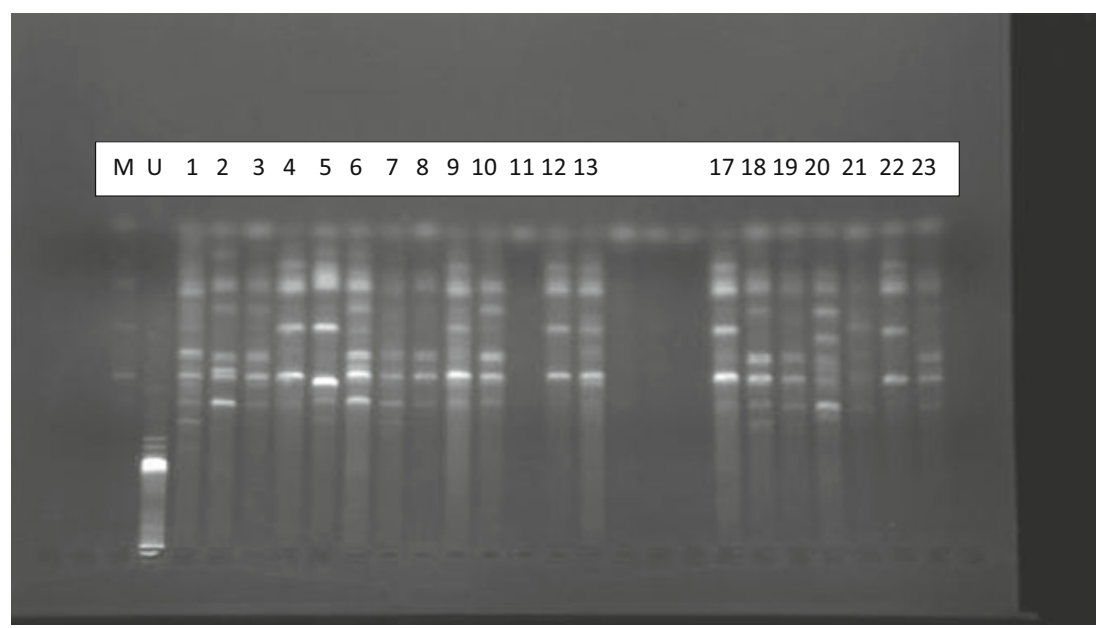


Fig. 5 Dendrogram of indigenous tree legume rhizobia based on combined HaeIII, RsaI, HpaI, HpaII and AluI restriction patterns of amplified 16S rRNA. The data were analysed using UPGMA in the BioNumerics program

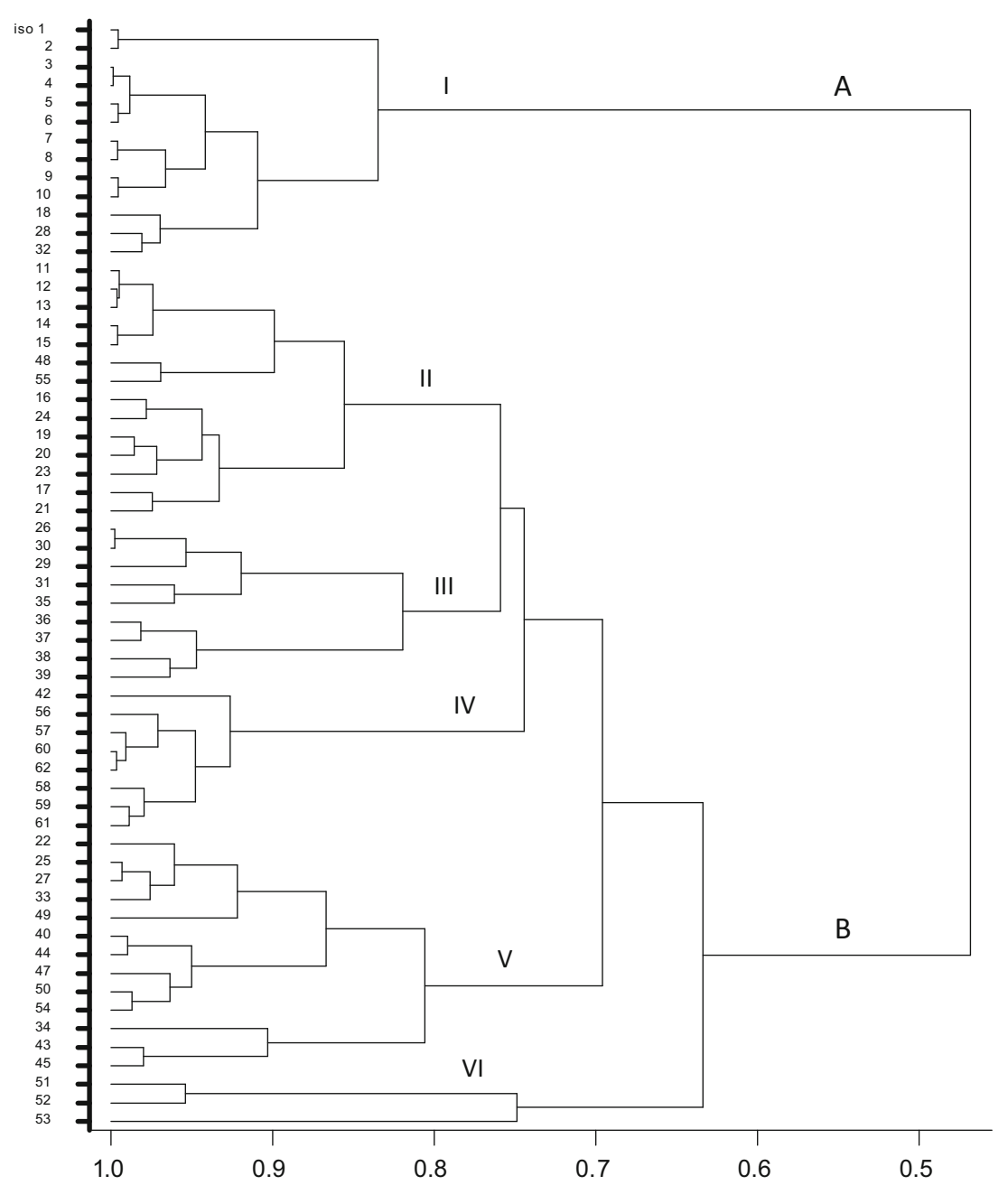

variations among the isolates and suggests that the soils harbour populations of highly diverse strains that nodulate the five tree legumes species. This finding is in agreement with the results obtained in other parts of the world (Ando and Yokoyama 1999; Niemann et al. 1997).
Characterization of the rhizobial isolates based on PCR of the ITS sequence provided several distinct band size indicating great variation among the isolates. The high level of ITS size heterogeneity is consistent with the findings by Zerhari et al. (1998), who performed an extensive study of the pheno-

Fig. 6 Patterns obtained with undigested ITS amplicons of some tree legume isolates

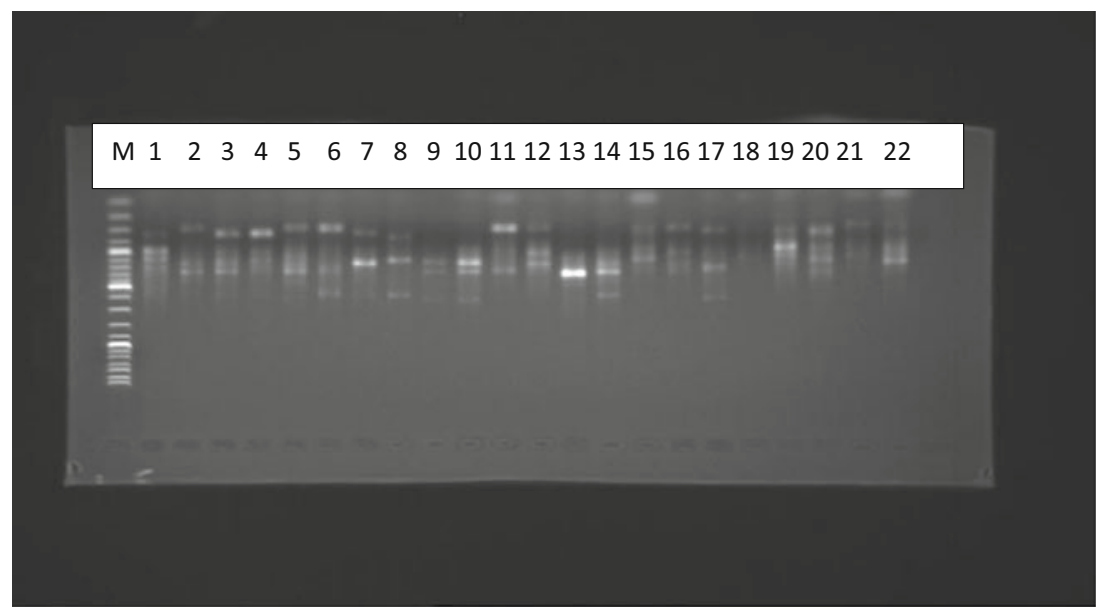


Fig. 7 Dendrogram of some indigenous tree legume rhizobia isolates based on undigested ITS patterns. The data were clustered by using UPGMA in the

BioNumerics program

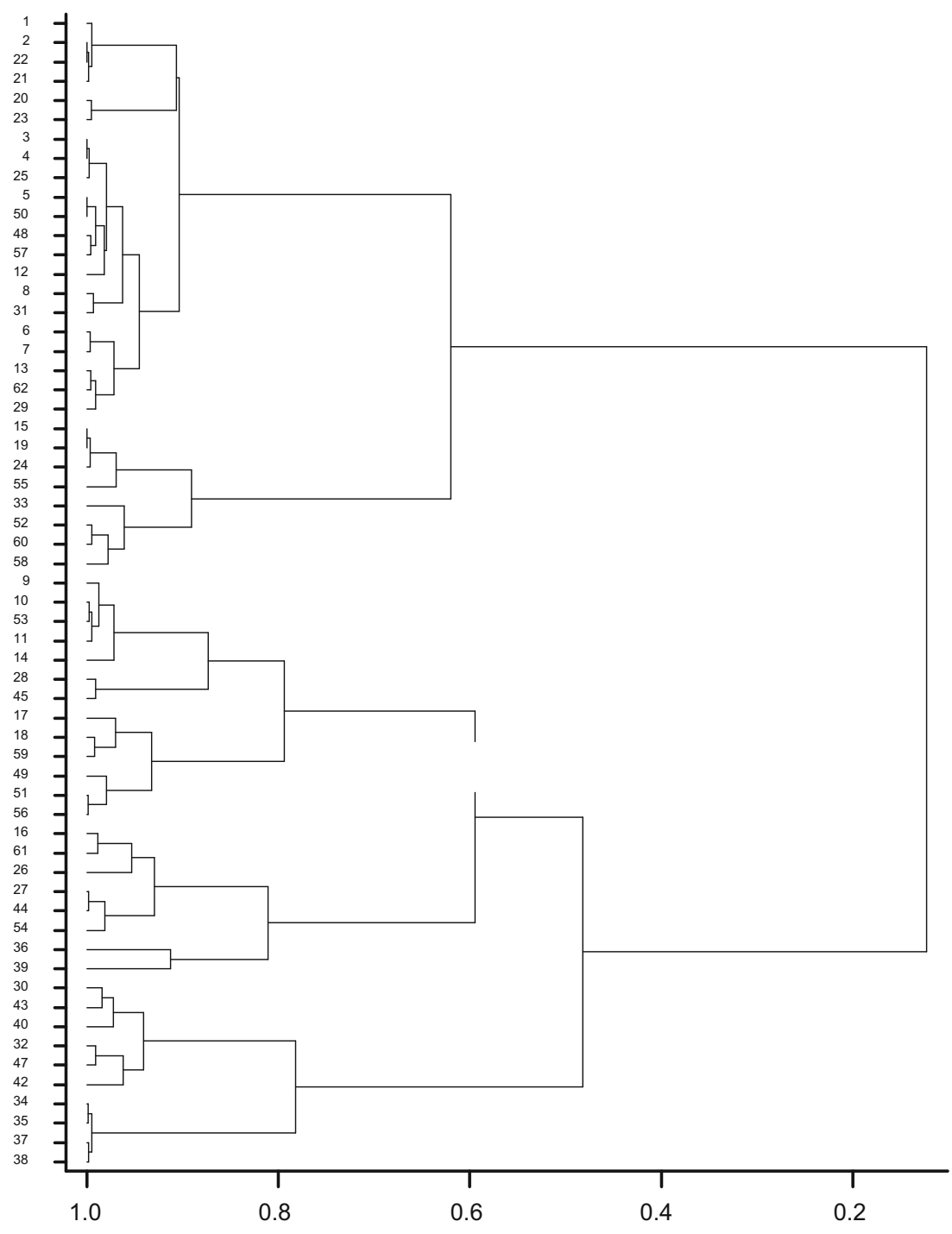

typic and genotypic characteristics of rhizobia nodulating Acacia spp. in Morocco and concluded that these rhizobia seem to belong to several different clusters. Such length variability of the ITS was also recorded by Laguerre et al. (1996), between genotypes within $R$. leguminosarum. However, further restriction of the ITS with three restriction enzymes did not result in any additional distinction among the strains examined. This finding is similar to results obtained by Khbaya et al. (1998), who investigated genetic diversity and phylogeny of several rhizobial strains that nodulate Acacia species using PCR with RFLP. Lack of major difference in the restriction patterns of the rhizobia ITS relative to their unrestricted sizes suggests that there is little sequence variability in the ITS among the tree nodulating rhizobia that cannot be revealed simply by RFLP analysis. The occurrence of a wide diversity of strains in any soil increases the opportunity for various legume hosts to find compactible rhizobia for nodulation.
Although all the characterization methods used, phenotypic or genotypic, revealed considerable diversity in the rhizobia that nodulated the different tree species, the molecular methods were superior for identification and classification.

Many developing countries do not have facilities for inoculant production and therefore need to rely on the indigenous rhizobia to nodulate their legumes. It can be concluded that the high diversity of tree-nodulating rhizobia found in this study and by others (Crow et al. 1981; Jarvis 1983; Padmonabhan et al. 1990), provides sufficient effective stains of indigenous rhizobia to enhance growth of native and introduced trees in the often N-depleted soils of the tropics.

Acknowledgments We wish to thank management of forest research institute of Ghana (FORIG) for providing pure seeds of the indigenous or introduced trees for the study. The principal author owes Apostle Dr. Kwadwo Safo a gratitude for providing financial support for the project. 
Open Access This article is distributed under the terms of the Creative Commons Attribution 4.0 International License (http:// creativecommons.org/licenses/by/4.0/), which permits unrestricted use, distribution, and reproduction in any medium, provided you give appropriate credit to the original author(s) and the source, provide a link to the Creative Commons license, and indicate if changes were made.

\section{References}

Amann RI, Ludwig W, Schieifer KH (1995) Phylogenetic identification and in situ detection of microbial cells without cultivation. Microbiol Rev 59:143-169

Ando S, Yokoyama T (1999) Phylogenetic analysis of bradyrhizobium strains nodulating soya-bean with reference to USDA strains of Bradyrhizobium. Can J Microbiol 45:639-645

Batzli JMC, Graves WR, Berkum PV (1992) Diversity among rhizobia effective with Robinia pseudoacacia. Appl Environ Microbiol 58: 2137-2143

Bontemps C, Rogel MA, Wiechmann A, Mussabekova A, Moody S, Simon MF, Moulin L, Elliott GN, Lacercat-Didier L, Dasilva C, Grether R, Camargo-Ricalde SL, Chen W, Sprent JI, MartínezRomero E, Young JPW, James EK (2015) Endemic Mimosa species from Mexico prefer alphaproteobacterial rhizobial symbionts. New Phytol 10:1111-13573

Brammer H, (1967) Soil of the Accra plains. Memoir No 3, Soil Research Institute, Ghana Academy of Sciences, Kumasi.

Bray RH, Kurtz LT (1945) Determination of total organic and available forms of phosphorus in soils. Soil Sci 59:39-45

Bremner JM (1965) Total nitrogen. In: Black CA (ed) Methods of soil analysis, part 2, Chemical and microbiological properties. Agronomy Monograph No 9, pp. 1149-1178

Brunel B, Rome S, Ziani R, Cleyet-Marel JC (1996) Comparison of nucleotide diversity and symbiotic properties of Rhizobium meliloti population from annual species of Medicago. FEMS Microbiol Ecol Lett 19:71-82

Cartwright CP, Stock F, Beekmann SE, Williams EC, Gill VJ (1995) PCR amplification of rRNA intergenic spacer regions as a method for epidemiologic typing of Clostridium difficle. J Clin Microbiol 33: 184-187

Chen WX, Li GS, Qi YL, Wang ET, Yuan HL, Li JL (1991) Rhizobium huakuii spp. nov. isolated from the root nodules of Astra galussinicus. Int J Syst Bacteriol 41:275-280

Cooper JE, Wood M, Bjourson AJ (1985) Nodulation of Lotus pedunculatus in acid rooting solution by fast-and slow-growing rhizobia. Soil Biol Biochem 17:487-492

Crow VL, Jarvis BDW, Greenwood RM (1981) Deoxyribonucleic acid homologies among acid-producing strains of Rhizobium. Int J Syst Bacteriol 31:152-172

Cunningham SD, Munns DN (1984) The correlation between extracellular polysaccharide production and acid tolerance in Rhizobium. Soil Sci Soc Am J 48:1213-1226

Day PR (1965) Particle fractionation and particle-size analysis. In: Black et al (Eds) Methods of soil analysis, Part 1. Agronomy 9: 545-567.

De Lajudie P, Willems A, Pot B, Dewettinck D, Maestrojuan G, Neyra M, Collins MD, Dreyfus B, Kersters K, Gillis (1994) Polyphasic taxonomy of rhizobia: emendation of the genus Sinorhizobium and description of Sinorhizobium meliloti comb. Nov. Sinorhizobium saheli sp. nov. Sinorhizobium teranga sp. nov. Int J Syst Bacteriol 44:715-733

Dreyfus BL, Dommergues YR (1981) Nodulation of Acacia species by fast and slow-growing tropical strains of Rhizobium. Appl and Environ Microbiol 41:97-99
Dupuy N, Willems A, Pot B, Dewettinck D, Maestrojuan G, Collins MD, Dreyfus B, Kersters K, Gillis M (1994) Phenotypic and Genotypic characterization of bradyrhizobia nodulating the leguminous tree Acacia albida. Int J Syst Bacteriol 44:461-473

FAO (2006) World reference base for soil resources. World soil resources reports no 103 F.A.O. Rome.

Felsenstein J (1985) Confidence limits on phylogenies: an approach using the bootstrap. Evolution 39:783-891

Fening, JO (1999) Diversity and symbiotic characteristics of cowpea Bradyrhizobium strains in Ghanaian soils. Ph.D thesis Dept of Soil Science, University of Ghana Legon.194p.

Galtier N, Gouy M, Gautier C (1996) SeaView and phylo-win, two graphic tools for sequence alignment and molecular phylogeny. Comput Appl Biosci 12:543-548

Gibson AH (1980) Methods for legumes in glasshouse and controlled environment cabinets. In: Bergersen FJ (ed) Methods for evaluating biological nitrogen fixation. John Wiley and Son Inc, New York, pp. 139-184

Graham PH, Draeger K, Ferrey ML, Conroy MJ, Hammer BE, Martinez E, Naarons SR, Quinto C (1994) Acid pH tolerance in strains of Rhizobium and Bradyrhizobium, and initial studies on the basis for acid tolerance of Rhizobium tropici UMR1899. Can J Microbiol 40: 198-207

Gurtler V (1993) Typing Clostridium difficile strains by PCRamplification of variable length 16S-23S rRNA spacer regions. J Gen Microbiol 139:3089-3097

Gurtler V, Stanisich VA (1996) New approaches to typing and identification of bacteria using the $16 \mathrm{~S}-23 \mathrm{~S}$ rDNA spacer region. Microbiol 142:3-16

Gyaneshwar P, Hirsch AM, Moulin L, Chen W-M, Elliott GN, et al. (2011) Legume-nodulating betaproteobacteria: diversity, host range, and future prospects. Mol Plant-Microbe Interact 24:1276-1288

Jarvis BDW (1983) Genetic diversity of Rhizobium strains which nodulate Leucaena leucocephala. Curr Microbiol 8:153-158

Jarvis BDW, Pankhurst CE, Patel JJ (1982) Rhizobium loti, a new species of legume root nodule bacteria. Int J Syst Bacteriol 32:378-380

Khbaya B, Neyra M, Normand P, Zerhari K, Filali-Maltouf A (1998) Genetic diversity of rhizobia that nodulate Acacia spp in Morocco assessed by analysis of rRNA genes. Appl and Environ Microbiol 64:4912-4917

Laguerre G, Mavingui MR, Allard MP, Charnay P, Louvrier SI, Mazurier K, Rigottier-Gois AN (1996) Typing of rhizobia by PCR DNA fingerprinting and PCR-restriction fragment length polymorphism analysis of chromosomal and symbiotic gene regions: application to Rhizobium leguminosarum and its biovars. App and Environ Microbiol 62:2029-2036

Lindstrom K, Jarvis BDW, Lindstrom PE, Patel (1983) DNA homology, phage typing and cross-nodulation studies of rhizobia infecting Galega species. Can J Microbiol 29:781-789

McInroy SG, Campbell CD, Haukka KE, Odee DW, Sprent JI, Wang WJ, Young JPW, Sutherland JM (1999) Characterization of rhizobia from African acacias and other tropical woody legumes using biology and partial 16S rRNA sequencing. FEMS Microbiol Lett 170: 111-117

Moreira FMS, Haukka K, Young JPW (1998) Biodiversity of rhizobia isolated from a wide range of forest legumes in Brazil. Mol Ecol 7: 889-895

Mpepereki S, Makonese F, Wollum AG (1997) Physiological characterization of indigenous rhizobia nodulating Vigna unguiculata in Zimbabwean soils. Symbiosis 22:275-292

Nick G, de Lajudie P, Eardly BD, Suomalainen S, Paulin L, Zhang X, Gillis M, Lindstrom K (1999) Sinorhizobium arboris sp. nov.and Sinorhizobium kostiense sp. nov., isolated from leguminous trees in Sudan and Kenya. Int J Syst Bacteriol 49:1359-1368

Niemann S, Puhler A, Tichy HV, Simon R, Selbitschka WJ (1997) Evaluation of the resolving power of three different DNA 
fingerprinting methods to discriminate among isolates of a natural Rhizobium meliloti population. J Appl Microbiol 82(4):477-484

Odee DW, Sutherland JM, Msksyisni ET, McInroy SG, Sprent JI (1997) Phenotypic characteristics and composition of rhizobia associated with woody legumes growing in diverse Kenya conditions. Plant Soil 188:65-75

Odee DW, Haukka K, McInroy SG, Sprent JI, Sutherland JM, Young JPW (2002) Genetic and symbiotic characterization of rhizobia isolated from tree and herbaceous legumes grown in soils from ecologically diverse sites in Kenya. Soil Biol Biochem 34:801-811

Padmonabhan S, Hirtz RD, Broughton WJ (1990) Rhizobia in tropical legumes. cultural characteristics of Bradyhizobium and Rhizobium sp. Soil Boil Biochem 125:1075-1080

Peech ME (1965) Hydrogen ion activity. In: Black CA, Evans DD, White JL, Ensininger LE, Clark FE (eds) Methods of soil analysis vol.2. Chemical and microbial properties. Amer Soc of Agron, Madison, pp. 914-926

Ponsonnet C, Nesme X (1994) Identification of Agrobacterium strains by PCR-RFLP analysis of pTi and chromosomal regions. Arch Microbiol 16:300-309

Sally AM, Melanie LI, Xiulan X, Sawsan E, Laura H (2010) Plant disease and nematode diagnosis: A laboratory manual. The Ohio State University, Department of Plant Pathology

Sanginga N, Mulongoy K, Ayanaba A (1989) Nitrogen fixation of field inoculated Leucaena leucocephala (Lam) de wit estimated by $\mathrm{N}$ 15 and the difference method. Plant Soil 117:269-274

Somasegaran P, Hoben HJ (1994) Hand book for rhizobia methods in Legume-Rhizobium technology. Springler-verlag, Heidelberg, Germany

Terefework Z, Nick G, Suomalainen S, Paulin L, Lindstrom K (1998) Phylogeny of Rhizobium galegae with respect to other rhizobia and agrobacteria. J Biotechnol 48:349-356
Trinick MJ (1980) Relationship among the fast growing rhizobia of Lablab purpureus, Leucaena leucocephala, Mimosa sp., Acacia farresiana and Sesbania grandiflora and their affinities with other rhizobial groups. J Appl Bacteriol 49:39-53

Turk D, Keyser HH (1992) Rhizobia that nodulate tree legumes: specificity of the host for nodulation and effectiveness. Can J Microbiol $38: 451-460$

Vincent JM (1970) A manual for the practical study of root-nodule bacterial. IPB handbook No 15 blackwell scientific publications, Oxford, p. 64

Walkley A, Black A (1934) An examination of the Degtjareff methods for determining soil organic matter and a proposed modification of the chromic and titration method. Soil Sci 37:29-38

Weaver RW, Frederick LR (1972) Effect of inoculums rate on competitive nodulation of Glycine max L, Merrill I Green houses studies. Agron J 66:229-236

Weisburg WG, Barns SM, Pelletier DA, Lane DJ (1991) 16S ribosomal DNA amplification for phylogenetic study. J Bacteriol 173:697-703

Wood M, Cooper JE, Bjourson AJ (1988) Response of Lotus rhizobia to acidity and aluminum in liquid culture and in soil. Plant Soil 107: 227-231

Zablotowicz RM, Focht DD (1981) Physiological characteristics of cowpea rhizobia: evaluation of symbiotic efficiency in Vigna unguiculata. Appl Environ Microbiol 41:679-685

Zerhari K, Aurag J, Filali-Maltouf (1998) Biodiversity of Rhizobium spp strains isolated from Acacia spp in south of Morocco. In: Elmerich C et al. (eds) Biological nitrogen fixation for the 21st century. Kluwer Academic Publishers, Dordrecht, The Netherlands

Zhang X, Harper R, Karisto M, Lindstorm K (1991) Diversity of Rhizobium bacteria isolated from the root nodules of leguminous trees. Int J Syst Bacteriol 41:104-113 